\title{
Chemical and Functional Properties of Blends Made from Unripe Plantain (Musa Paradisiaca) and African Yam Bean (Sphenostylis Stenocarpa) Flours for Stiff Dough (Àmàlà) Preparation
}

\author{
${ }^{1}$ SALOME, KK; ${ }^{* 2}$ AWOFADEJU, OFJ; ${ }^{1}$ OLAPADE, AA \\ ${ }^{I}$ University of Ibadan, Department of Food Technology, Oyo State, Nigeria \\ $2^{2 *}$ Forestry Research Institute of Nigeria, Department of Forest Product Development and Utilization, Jericho Hill Ibadan, Oyo State, \\ Nigeria \\ *Corresponding Author Email: yemluck07@yahoo.com; Awofadeju.of@frin.gov.ng; Tel: +2348034990369
}

\begin{abstract}
Research efforts in developing countries have focused on the improvement of protein quality of food products due to mass malnutrition. The inclusion of unripe plantain into African yam bean flours for the preparation of stiff dough (Amala) was studied. The ratios of unripe plantain into African yam bean are 100:0, 90:10, 80:20, 70:30, 60:40 and 50:50. Chemical and functional properties of composite flour as well as overall acceptability of the product were evaluated. The result of moisture content is within safe limit to ensure shelf stability. Crude protein (6.87-12.98) and ash (2.43-6.57\%) increases with increasing proportion of African yam bean into unripe plantain flours, while carbohydrate (66.27-56.77) and crude fibre (1.46-1.11\%) decreases. The bulk density ranged from $(0.92-3.34 \mathrm{~g} / \mathrm{mL})$, water absorption capacity $(1.07-1.60 \%)$, least gelation capacity $\left(4.10-14.23 \%\right.$ ), and swelling power $1.49-1.77 \mathrm{~g} / \mathrm{g}$ at $50{ }^{\circ} \mathrm{C}, 1.54-1.88$ at $60{ }^{\circ} \mathrm{C}, 2.63-2.89$ at $70^{\circ} \mathrm{C}$ and $4.42-6.60 \mathrm{~g} / \mathrm{g}$ at $80^{\circ} \mathrm{C}$, respectively. The solubility index ranged from $1.49-1.77$ at $50{ }^{\circ} \mathrm{C}, 1.54-1.88$ at $60{ }^{\circ} \mathrm{C}, 2.63-2.89$ at 70 ${ }^{\circ} \mathrm{C}$ and $4.42-6.60 \mathrm{~g} / \mathrm{g}$ at $80^{\circ} \mathrm{C}$. The sensory evaluation showed no significant difference in taste, colour, texture/mouth feel and aroma while sample with $30 \%$ African yam bean flour has the highest value in overall acceptability. Enrichment of unripe plantain with African yam bean flours significantly increases its nutritional value which has the potential to combat protein-energy malnutrition and micronutrient deficiencies in Nigeria and Africa as a whole.
\end{abstract}

\section{DOI: https://dx.doi.org/10.4314/jasem.v25i5.8}

Copyright: Copyright $(92021$ Salome et al. This is an open access article distributed under the Creative Commons Attribution License (CCL), which permits unrestricted use, distribution, and reproduction in any medium, provided the original work is properly cited.

Dates: Received: 20 March 2021; Revised: 27 April 2021; Accepted: 07 May 2021

Keywords: African yam bean, unripe plantain, malnutrition, composite flours, enrichment

Carbohydrate based starchy foods such as cassava, yam, plantain, maize, rice among others are the staple food in most developing countries especially in Africa leading to various malnutrition problems. Protein-rich foods are usually expensive and not as abundant as carbohydrate foods and the scarcity has greater impact on children, lactating mothers and elderly people whose physical and mental development requires nutritionally balanced diets. Complementing, supplementing and enriching these carbohydrate starchy based foods with plant protein from various legumes can provide the required balanced nutrients. Grain legumes constitute main source of protein in the diets of average Nigerians. The most important ones are cowpea (Vigna unguiculata), soybean (Glycine max), pigeon pea (Cajanus cajan) and groundnut (Arachis hypogaea). However, there are other pulses that could help meet dietary needs but are cultivated only in localized areas and are underutilized. These under-exploited legumes include African yam bean (AYB) (Sphenostylis stenocarpa) and bambara groundnut (Vigna subterranea). AYB is a hard-tocook under-exploited leguminous plant grown extensively in Western Africa (Enujiugha et al., 2012; Uchegbu, 2015), Eastern and Central Africa (Bhat and Karim, 2009). In many areas where it is cultivated, AYB is regarded as a security crop for fallow farmlands in the preparation for a new planting season and primarily consumed as staple crops. It is a perennial crop (Nwosu, 2013), commonly or mainly planted by local farmers for subsistence (Klu et al., 2001; Enujiugha et al., 2012). The plant when harvested gives an edible seed and tuber (Ajibola and Olapade, 2016) which is widely consumed in the South-eastern part of Nigeria (Idowu, 2014) and other parts of West Africa. Nutritionally, the seed (Figure 1) is rich in protein ranging between 12 and 30\% (Nwokolo, 1987a; Edem et al., 1990; Adeyeye et al., 1994; Klu et al., 2001; Nwosu, 2013; Ndidi et al., 2014; Abioye et al., 2015; Ade-Omowaye et al., 2015; Duodu and Apea-Bah, 2017; Anya and Ozung, 2019). The proteins in AYB compares favourably with those in pigeon pea, chick pea, Bambara groundnut and common bean. It is also rich in dietary fiber (Ndidi et al., 2014; Anya and Ozung, 2019), carbohydrates (Eromosele et al., 2008; Ajibola and Olapade, 2016). 
Because AYB is rich in protein and other nutrients, it has been used in the development of fortified and enriched foods. Food enrichment involves the addition of nutrients (macro and micro alike) to foods to compensate for losses that may occur during processing or present in minute amount. The bean has been used in the development of cookies and snacks (Idowu, 2014; Igbabul et al., 2015), an imitation yoghurt (Amakoromo et al., 2012), composite flour with rice and brown cowpea seeds (Iwe et al., 2016), breakfast meals (Babarinde et al., 2019), traditional snack food such as kokoro (Idowu, 2015b), maize AYB meal composite (Idowu, 2015a) and AYB enriched fufu (Aniedu and Aniedu, 2014). Therefore, AYB can be fortified or enriched other foods with low in protein to address protein malnutrition among the susceptible population. The bean has been touted for use in addressing the problem of food security in Africa because they are indigenous (Klu et al., 2001; Abioye et al., 2015). Due to various nutrients possessed in AYB, it is a good candidate for the development of new functional foods for consumer acceptability, hence, the need for the enrichment in unripe plantain flour.

Plantain (Musa paradisiaca) is a rhizomatous perennial crop used as a source of starchy staple for millions of people in Nigeria (Adeniyi et al., 2006). Over 2.11 million metric tons of plantains are produced in Nigeria annually which contributes substantially to the nutrition of subtropical local population (Akinsanmi, 2015). Unripe plantain is consumed mainly for its vitamins and mineral contents, also includes many medicinal and therapeutic properties enriching the heart and contain some amount of serotonin dilating the arteries, improves blood flow and reduces homocysteine (a condition that causes coronary artery disease and stroke) (Eleazu et al., 2010; Eleazu et al., 2013). In addition, its richness in potassium makes it heartfriendly by preventing heart attack and hypertension through the control of heart rate and blood pressure in the body cell. Also, its fibre content is very helpful in reducing cholesterol level which reduces the risk of developing any heart diseases; treatment of anaemia and neuritis in the presence of vitamin B6, helps in curing neuritis (inflammation of the nerve) and anaemia; a medical condition of having low red blood cells in the blood causing weaknesses; weight loss and healthy eating because it is relatively low in carbohydrates, high fibre content, essential minerals and vitamins (Eleazu et al., 2013). Therefore, consuming unripe plantain helps the circulatory and digestive system, reduces constipation by making bowel movement easier due to its high fibre content and prevention of diabetes owing to its low sugar content compared to ripe or over-ripe plantain. The propensity of individuals to develop diabetes and obesity is due to the increased consumption of carbohydrate rich foods with a high glycemic index (Willett et al., 2002; Foster et al., 2003). However, plantain flour can make good stiff dough called amala either singly or in combination with yam flour (Abulude and Ojediran, 2006). Amala is regarded as a starchy gel or stiff dough traditionally prepared from yam (Dioscorea spp) flour (Abiodun and Akinoso, 2014). Amala is majorly consumed in the South Western part of Nigeria (Abiodun and Akinoso, 2014), Ghana where it is called kokonte (Jimoh and Olatidoye, 2009). According to Awoyale et al. (2010), amala contains majorly carbohydrates and as a result does not provide adequate nutrients especially among rural dwellers. Efforts are therefore geared towards improving the nutritional value of such staples through incorporation of legumes and protein-rich plant (AYB) foods. For example, moringa oleifera leaf powder into unripe plantain with ratios ranging from 0.5 to $2.0 \%$ are generally accepted with the exception of $2.5 \%$ moringa oleifera leaf plant recorded low acceptability (Falade and Oyeyinka, 2015); supplementing yam flour with $35 \%$ distillers spent grain (Awoyale et al., 2010) and yam flour fortified with 39\% soybean flour (Jimoh and Olatidoye, 2009). The use of AYB flour to enhance the nutritional composition of unripe plantain flour has not been investigated. Thus, the objective is geared towards producing composite flour by enriching unripe plantain with African Yam Bean (AYB) flours, determining chemical and functional properties of the composite flours as well as its product acceptability.

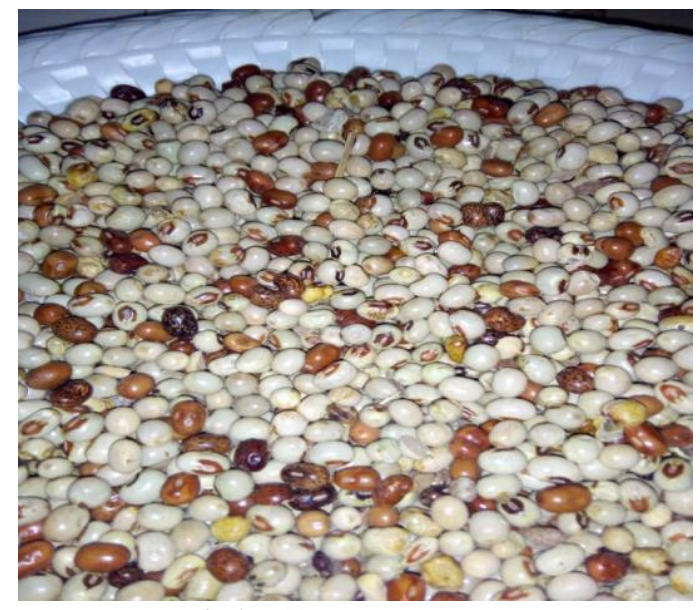

Fig 1. African yam bean seeds

\section{MATERIALS AND METHODS}

Collection of Materials: Bunches of matured unripe plantain free from physical damage and bruises are obtained alongside African Yam Bean from Bodija market, Ibadan. 
Preparation of Unripe Plantain Flour: The processing of unripe plantain flour is prepared following the method of Falade and Olugbuyi, (2010). Fingers of matured unripe plantain were removed, rinsed in clean water and peeled manually with hives. The sliced pulp was blanched in boiling water for 15 minutes to inactivate enzymes and dried at $50{ }^{\circ} \mathrm{C}$ for $24 \mathrm{~h}$ in a hot air oven (D-37520, Thermo Fisher Scientific, South Africa). Thereafter, the dried plantains were milled in a Qlink blender (Model No. QBL - 1861A; Turinar Corp. No 1682, Fu-Yong Ave, Nan-Tun County, Shang-Hai, China) and sieved (Sieve aperture size: $350 \mu \mathrm{m})$ into flour, sealed in a polythene nylon and used for analysis.

Preparation of African Yam Bean Flour: African yam bean flour was produced according to the method described by Ndidi et al. (2014). An African yam beans seed was sorted manually to remove foreign materials. The seeds were soaked in water $(1: 5 \mathrm{w} / \mathrm{v})$ for about $4 \mathrm{hrs}$ at room temperature, drained, rinsed, dehulled manually and oven dried at $55{ }^{\circ} \mathrm{C}$ for about 15 h (D-37520, Thermo Fisher Scientific, South Africa). The dried bean was milled into flour using Qlink blender (Model No. QBL - 1861A; Turinar Corp. No 1682, Fu-Yong Ave, Nan-Tun County, Shang-Hai, China). The flour obtained was sieved to pass through a $250 \mu \mathrm{m}$ British standard sieve to obtain flour of uniform size, packaged in polythene nylon and stored at $5{ }^{\circ} \mathrm{C}$.

Unripe Plantain - African Yam Bean flours formulation: African Yam Bean flour was added to unripe plantain flour in concentration ranging from 0 , $10,20,30,40$ and $50 \%$ on dry weight basis (Table 1), and samples are coded with GAB, ORE, TAM, MFY, MED and KSK, respectively. These levels of incorporation were adopted following the literature (Aniedu and Aniedu, 2014) with slight modification. Unripe plantain flour without AYB (0\%) served as the control.

Table 1: Ratio of Unripe Plantain Flour to African Yam Bean Flour for the Production of Composite Flour

\begin{tabular}{ll}
\hline Samples & $\begin{array}{l}\text { Unripe plantain/African } \\
\text { Yam Bean flours ratio }\end{array}$ \\
\hline GAB & $100: 0$ \\
ORE & $90: 10$ \\
TAM & $80: 20$ \\
MFY & $70: 30$ \\
MED & $60: 40$ \\
KSK & $50: 50$ \\
\hline
\end{tabular}

Proximate Composition of Composite Flour Moisture content: Moisture, ash and fat contents of unripe plantain and AYB flours were determined using standard methods (AOAC, 2000). The protein content was determined by Kjeldahl method ( $\mathrm{N}$ x 6.25) and total carbohydrate was calculated by difference.

Functional Properties of Enriched Unripe Plantain Flour: Water absorption capacity: Water absorption capacity of enriched unripe plantain flour was determined by Oyeyinka et al. (2013) with few modifications. Briefly, two gram of the sample was weighed into a dry, clean centrifuge tube. Water (10 $\mathrm{mL}$ ) was poured into the tube and properly mixed by vortexing. The suspension was allowed to stand for 30 min and centrifuged (Centrifuge Model: Ependorf $5810 R$, Germany) at $3,500 \times g$ for $30 \mathrm{~min}$. Supernatant was discarded and the tube with its content reweighed. Gain in weight expressed, as a percentage of water bound, was calculated as the WAC of the sample.

Bulk density: Bulk density was determined using the method as described by Oyeyinka et al. (2013). A measuring cylinder $(100 \mathrm{~mL})$ was filled with composite flour to mark $(100 \mathrm{~mL})$ and tapped the side of the measuring cylinder several times until the flour was constant. The bulk density was expressed as the ratio of the bulk weight and volume of the container $(\mathrm{g} / \mathrm{mL})$.

Swelling power and solubility: Swelling power and solubility of the flours was determined according to the method described by AOAC (2000). About $1 \mathrm{~g}$ of each sample was weighed into $100 \mathrm{~mL}$ conical flask. About $15 \mathrm{~mL}$ of distilled water was added, shake for 5 mins at low speed and the sample was transferred into water bath and heated for 40 mins at $80-85{ }^{\circ} \mathrm{C}$ with constant stirring. The suspension was centrifuge (Centrifuge model: Ependorf 5810R, Germany) at $3400 x$ for 20 mins and the supernatant discarded. Swelling power was obtained by weighing the residue after centrifugation and dividing by original weight of flour on dry weight basis.

Least gelation concentration: This was determined according to the method described by Adebowale et al. (2005). Diet suspensions of about 2-20 \% (w/v) in $5 \mathrm{~mL}$ of distilled water in test tubes were made and the suspensions were heated for $1 \mathrm{~h}$ in boiling water bath followed by rapid cooling under running cold tap water and subsequently at $4{ }^{\circ} \mathrm{C}$ for $2 \mathrm{~h}$. The gelation concentration was determined as the concentration when the diet from inverted test tube did not slip.

Preparation of stiff dough (Amala): Amala was prepared by the method of Karim et al. (2015). Briefly, both control and composite flour (200 g) was prepared separately by pouring the flour into boiling water with continuous stirring until a homogenous paste was formed. The paste was added little water, covered and 
left on the fire for about 5 min to cook. It was further stirred, packed and wrapped with thin labeled polythene wraps.

Sensory evaluation of stiff dough (Amala): A 9-point hedonic preference scale and a multiple comparison test were used to assess the acceptability of amala made from AYB and unripe plantain flours and $100 \%$ unripe plantain flour using 30 trained panelists. Panelists were selected from student of the Department of Food Technology, University of Ibadan, Nigeria. The selected students were those accustomed to eating amala. Prior to the sensory analysis, they were screened with respect to their interest and ability to differentiate food sensory properties. The samples were evaluated for colour, aroma, taste, texture/mouth feel and overall acceptability.

Data Analysis: All experiments were conducted in duplicate. Data were analysed using Statistical
Analysis of Variance (ANOVA) SPSS version 16.0. Means were separated by Duncan Multiple Range Test (DMRT) and significance difference was taken at 5\% confidence limit.

\section{RESULTS AND DISCUSSION}

Proximate Composition: Carbohydrate (approx. 57$66 \%$ ) was the major component of the blends followed by protein (approx. 7-13\%), fat (approx. 8-11\%), moisture (approx. 6- 8\%) and ash (approx. 2-7\%) while fibre $(1.11-1.85 \%)$ was present in relatively small amount (Table 2). AYB flour addition slightly decrease the carbohydrate and moisture content of the blends (with the exception of TAM and MFY). The slight decrease in moisture and carbohydrate had positive impact on the blends by prolonging the shelf life and served as a balanced meal for diabetic patient. Moisture contents of samples GAB and ORE are not significantly different $(\mathrm{p}<0.05)$ to each other while other samples are significantly different $(p<0.05)$.

Table 2: Proximate composition of composite flour made from blends of plantain flour and African Yam Bean flour (\%)

\begin{tabular}{lllllll}
\hline Sample & Moisture & Protein & Fat & Fibre & Ash & Carbohydrate \\
\hline GAB & $7.37 \pm 0.19^{\mathrm{c}}$ & $6.87 \pm 0.12^{\mathrm{f}}$ & $8.33 \pm 0.10^{\mathrm{e}}$ & $1.46 \pm 0.02^{\mathrm{e}}$ & $2.43 \pm 0.02^{\mathrm{f}}$ & $66.27 \pm 0.01^{\mathrm{b}}$ \\
ORE & $7.32 \pm 0.15^{\mathrm{c}}$ & $7.44 \pm 0.25^{\mathrm{e}}$ & $10.89 \pm 0.01^{\mathrm{c}}$ & $1.47 \pm 0.02^{\mathrm{e}}$ & $3.84 \pm 0.02^{\mathrm{d}}$ & $61.94 \pm 0.01^{\mathrm{d}}$ \\
TAM & $7.31 \pm 0.13^{\mathrm{b}}$ & $8.35 \pm 0.11^{\mathrm{d}}$ & $8.00 \pm 0.06^{\mathrm{f}}$ & $1.11 \pm 0.01^{\mathrm{f}}$ & $4.00 \pm 0.06^{\mathrm{c}}$ & $62.02 \pm 0.10^{\mathrm{d}}$ \\
MFY & $6.84 \pm 0.33^{\mathrm{d}}$ & $10.77 \pm 0.75^{\mathrm{c}}$ & $8.01 \pm 0.12^{\mathrm{f}}$ & $1.11 \pm 0.00^{\mathrm{f}}$ & $4.28 \pm 0.02^{\mathrm{b}}$ & $62.13 \pm 0.12^{\mathrm{c}}$ \\
MED & $6.47 \pm 0.35^{\mathrm{e}}$ & $11.89 \pm 0.55^{\mathrm{b}}$ & $9.67 \pm 0.15^{\mathrm{d}}$ & $1.11 \pm 0.01^{\mathrm{f}}$ & $3.47 \pm 0.10^{\mathrm{e}}$ & $60.88 \pm 0.01^{\mathrm{e}}$ \\
KSK & $6.09 \pm 0.12^{\mathrm{f}}$ & $12.98 \pm 0.01^{\mathrm{a}}$ & $8.33 \pm 0.02^{\mathrm{e}}$ & $1.85 \pm 0.02^{\mathrm{d}}$ & $6.57 \pm 0.01^{\mathrm{a}}$ & $56.77 \pm 0.02^{\mathrm{f}}$ \\
\hline
\end{tabular}

Values within a column with different superscripts are significantly different $(p<0.05)$

KEY: GAB - $100 \%$ plantain flour; ORE - 90\% plantain flour blended with $10 \%$ African Yam Bean flour; TAM - $80 \%$ plantain flour blended with 20\% African Yam Bean flour; MFY - 70\% plantain flour blended with 30\% African Yam Bean flour; MED - $60 \%$ plantain flour blended with 40\% African Yam Bean flour; KSK - 50\% plantain flour blended with 50\% African Yam Bean flour

These values are within the recommended moisture value $(14.50 \%)$ for safety (Abioye et al., 2015). Although moisture content largely depend on postharvest drying, handling and storage conditions. The protein composition of all samples are significantly different $(\mathrm{p}<0.05)$ to each other. Apparently, increase in AYB flour into unripe plantain flour increases protein and ash content. The protein content of the blends were very similar and substantially affected (positively) by the addition of AYB as reported by (Ndidi et al., 2014) in the variation with processing conditions of boiled and roasted AYB. Hence, statement agrees with the method used in the processing of AYB in this study which reflected in the blends. Furthermore, several factors including different seed accession, planting location, agronomic practices as well as seasons of the year when the bean was planted may influence their proximate composition when compared data with other authors. The bean is low in fat, the low-fat content is expected since AYB is classified as a pulse. The fat contents of samples GAB and KSK, as well as TAM and MFY are not significantly different $(\mathrm{p}<0.05)$ to each other while samples ORE and MED are significantly different $(\mathrm{p}<0.05)$. Pulse, unlike oil seeds, has very low fats usually less than $10 \%$ but might sometimes be slightly higher (Ade-Omowaye $e t$ al., 2015). Earlier author added that African yam bean contains an amount of carbohydrate (49.88-63.51\%), comparable to some other legumes namely cowpea, Bambara and pigeon pea. Preparation of fufu fortified with AYB flour was reported by Aniedu and Aniedu (2014), as increased in protein and ash in all fortified samples was reported. AYB was used to enrich ogi and agidi known as maize gruels (Ukegbu et al., 2014) with no nutrients required for growth. AYB enriched with plantain flour for the preparation of amala (Akinsola et al., 2018), reported increase in protein value (approx. 27\%); inclusion of AYB in the preparation of Tuwo (Idowu 2015a) with increase in protein and ash content. The last two authors concurred with the observations noted in this study.

Functional Properties of the Composite Flour: The bulk density of the composite flour ranges from 0.92 to $3.34 \mathrm{~g} / \mathrm{mL}$ (Table 3). Sample MFY had the highest bulk density and is significantly different $(\mathrm{p}<0.05)$ 
from the other blends. The values achieved in this study falls within the range reported by Falade and Olugbuyi (2010) in the fortification of plantain flour. Bulk density of a food material is important in relation to its packaging. Increase in bulk density is desirable because it offer greater packaging advantage, as greater quantity may be packed with constant volume (Falade and Oyeyinka, 2014).

Table 3: Functional properties of the composite flour made from blends of plantain flour and African Yam Bean flour

\begin{tabular}{llll}
\hline Sample & Bulk Density $(\mathbf{g} / \mathbf{m L})$ & WAC & LGC $(\%)$ \\
\hline GAB & $0.92 \pm 0.01^{\mathrm{f}}$ & $1.07 \pm 0.01^{\mathrm{f}}$ & $6.10 \pm 0.10^{\mathrm{e}}$ \\
ORE & $1.12 \pm 0.01^{\mathrm{e}}$ & $1.60 \pm 0.10^{\mathrm{c}}$ & $4.10 \pm 0.10^{\mathrm{f}}$ \\
TAM & $0.92 \pm 0.01^{\mathrm{f}}$ & $1.35 \pm 0.01^{\mathrm{e}}$ & $6.10 \pm 0.10^{\mathrm{e}}$ \\
MFY & $3.34 \pm 0.01^{\mathrm{d}}$ & $1.60 \pm 0.10^{\mathrm{c}}$ & $14.23 \pm 0.20^{\mathrm{c}}$ \\
MED & $1.12 \pm 0.01^{\mathrm{e}}$ & $1.52 \pm 0.01^{\mathrm{c}}$ & $6.23 \pm 0.21^{\mathrm{e}}$ \\
KSK & $0.92 \pm 0.01^{\mathrm{f}}$ & $1.42 \pm 0.01^{\mathrm{d}}$ & $8.17 \pm 0.15^{\mathrm{d}}$ \\
\hline
\end{tabular}

Values within a column with different superscripts are significantly different $(\mathrm{p}<0.05)$

KEY: GAB - 100\% plantain flour; ORE - 90\% plantain flour blended with $10 \%$ African Yam Bean flour; TAM - $80 \%$ plantain flour blended with 20\% African Yam Bean flour; MFY - 70\% plantain flour blended with $30 \%$ African Yam Bean flour; MED - $60 \%$ plantain flour blended with 40\% African Yam Bean flour; KSK - 50\% plantain flour blended with 50\% African Yam Bean flour

Bulk density is affected by the particle size and density of the flour (Adebowale et al., 2008), also enhances dispersibility and reduction of paste thickness. The water absorption capacity (WAC) of the blends ranged from 1.07 to $1.60 \%$ with the lowest value appeared in $100 \%$ plantain flour. WAC of sample GAB is significantly different $(\mathrm{p}<0.05)$ from the other samples, there is no significant difference in sample ORE, MFY and MED as well as sample TAM and KSK. The water absorption capacity (WAC) observed in this study is probably related to the low viscosity patterns and weak internal organization resulting from starch granules as reported by Akinsola et al. (2021) who worked on instant plantain flake enriched with egg parts. Water absorption capacity is the ability of a product to associate with water under limiting conditions (Singh, 2001). The least gelation concentration (LGC) of the composite flour ranged from 4.10 to $14.23 \%$. Least gelation concentration of the samples are significantly different $(\mathrm{p}<0.05)$ except that of sample GAB, TAM and MED which are not significantly different from each other. The least gelation concentration is the lowest protein concentration at which gel remained in the inverted tube was used as index of gelation capacity (Akinsola et al., 2021).

Swelling Power (SP): Swelling power provide evidence of the magnitude of the interaction between starch chains within the amorphous and crystalline domain. Swelling power is temperature and $\mathrm{pH}$ dependent. The swelling power (SP) of the composite flour is shown in Figure 2. At $50{ }^{\circ} \mathrm{C}$, swelling power ranged from 1.49 to $1.77 \mathrm{~g} / \mathrm{g}$ with sample $\mathrm{GAB}$ significantly different $(\mathrm{p}<0.05)$ from all other samples; at $60{ }^{\circ} \mathrm{C}$ ranged from 1.54 to $1.88 \mathrm{~g} / \mathrm{g}$ with samples ORE, TAM and MED significantly different $(\mathrm{p}<0.05)$; at $70{ }^{\circ} \mathrm{C}$ ranged from 2.63 to $2.89 \mathrm{~g} / \mathrm{g}$. All samples are not significantly different from each other. of the micellar network within the granules.

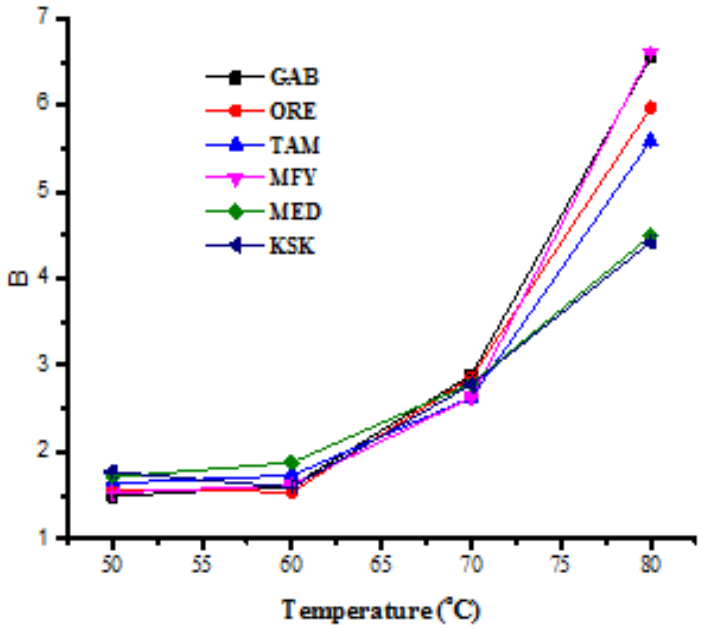

Fig 2 Swelling power composite flour made from blends of plantain flour and African Yam Bean flour (g/g)

KEY: GAB - $100 \%$ plantain flour; ORE - $90 \%$ plantain flour blended with $10 \%$ African Yam Bean flour; TAM - $80 \%$ plantain flour blended with 20\% African Yam Bean flour; MFY - 70\% plantain flour blended with 30\% African Yam Bean flour; MED $60 \%$ plantain flour blended with $40 \%$ African Yam Bean flour; KSK - 50\% plantain flour blended with $50 \%$ African Yam Bean flour

The swelling power at $80{ }^{\circ} \mathrm{C}$ ranged from 4.42 to 6.60 $\mathrm{g} / \mathrm{g}$ with sample ORE and TAM significantly different $(\mathrm{p}<0.05)$ from all other samples. Fluctuation in SP observed vary at different temperature, indicating an extent of associative forces like protein and carbohydrate within the food sample. This explains the amount of water needed to change a given dry sample to its visco-elastic form (Daramola and Osanyinlusi, 2006). SP and water absorption capacity are important parameters which ultimately determine sample consistency and compositional structure (Akinsola et al., 2018; Ayo-Omogie and Ogunsakin, 2013). According to Riaz-Mian and Swanmylingappa (2006) 
and Adebowale et al. (2005), swelling power is largely controlled by the strength and character.

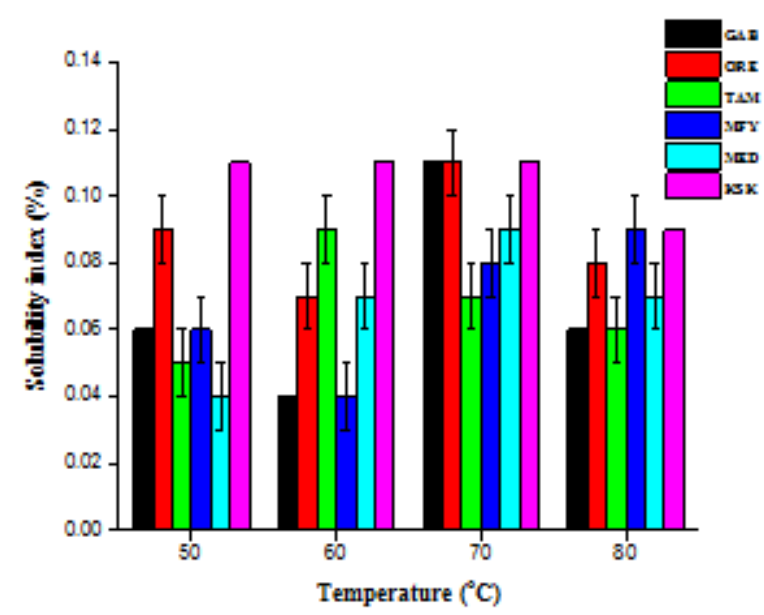

Fig 3 Solubility index of the composite flour made from blends of unripe plantain and African Yam Bean flours

KEY: GAB - 100\% plantain flour; ORE - 90\% plantain flour blended with 10\% African Yam Bean flour; TAM - 80\% plantain flour blended with 20\% African Yam Bean flour; MFY - 70\% plantain flour blended with 30\% African Yam Bean flour; MED . $60 \%$ plantain flour blended with $40 \%$ African Yam Bean flour; KSK - 50\% plantain flour blended with 50\% African Yam Bean flour

Solubility Index: The Figure 3 shows the solubility index of the composite flour made from blends of unripe plantain and African yam bean flours. Solubility can be expressed as a percentage of the mass of solubilised starch to the mass of dry starch sample. At 50 and $60{ }^{\circ} \mathrm{C}$, when gelatinization has not fully occurred, solubility ranged from 1.49 to $1.77 \%$ and 1.54 to $1.88 \%$ respectively. The solubility is associated with hydrophilic and ease of disruption of the starch granules, chain-length disruption of amylopectin. Increasing solubility was due to leaching out of the swollen granules on cooking. There was an increase in solubility index as the temperature increases, at 70 and $80^{\circ} \mathrm{C}$ where full gelatinization has occurred, the solubility index ranged from 2.63 to 2.89 $\%$ and 4.42 to $6.60 \%$ respectively. At $50{ }^{\circ} \mathrm{C}$, sample $\mathrm{GAB}$ is significantly different $(\mathrm{p}<0.05)$ from the others, while at $60^{\circ} \mathrm{C}$, sample ORE, TAM and MED are significantly different from the other samples. All the samples are not significantly different from each other at $70{ }^{\circ} \mathrm{C}$, while samples ORE and TAM are significantly different $(\mathrm{P}<0.05)$ to others at $80{ }^{\circ} \mathrm{C}$.

Sensory Evaluation: The sensory properties of the stiff dough (Amala) made from the composite flour in Table 4 . The colour ranged from 6.20 to 7.00 , all the samples have no significant difference, which is as a result of the very dark colour of unripe plantain flour. Sample MFY and KSK have the most preferred colour while sample MED is the least preferred. The aroma ranged from 6.27 to 6.90 , all the samples have no significant difference but sample TAM has the most preferred aroma while sample MED is the least preferred. The taste ranged from 6.30 to 6.80 , all the samples have no significance difference but sample KSK has the most preferred aroma while sample ORE is the least preferred. The texture/ mouth feel ranged from 6.23 to 6.90 , all the samples are not significantly different from each other, but sample MFY has the most preferred aroma while sample ORE is the least preferred. The overall acceptability ranged from 6.50 to 7.10 , all the samples are not significantly different from each other, but sample MFY has the most preferred aroma while sample MED is the least preferred. Also, sample MFY is the most preferred sample with highest mean value in colour, texture/mouth feel and overall acceptability.

Table 4. Sensory evaluation of Amala prepared from composite flour made from blends of plantain flour and African Yam Bean flour

\begin{tabular}{llllll}
\hline Samples & Colour & Aroma & Taste & $\begin{array}{l}\text { Texture/M } \\
\text { outh feel }\end{array}$ & $\begin{array}{l}\text { Overall } \\
\text { acceptability }\end{array}$ \\
\hline GAB & $6.87 \pm 1.22^{\mathrm{f}}$ & $6.40 \pm 1.59^{\mathrm{f}}$ & $6.53 \pm 1.63^{\mathrm{f}}$ & $6.53 \pm 1.38^{\mathrm{f}}$ & $6.87 \pm 1.41^{\mathrm{f}}$ \\
ORE & $6.70 \pm 0.92^{\mathrm{ef}}$ & $6.47 \pm 1.04^{\mathrm{f}}$ & $6.30 \pm 1 . .12^{\mathrm{f}}$ & $6.23 \pm 1.48^{\mathrm{f}}$ & $6.93 \pm 1.17^{\mathrm{f}}$ \\
TAM & $6.73 \pm 1.05^{\mathrm{ef}}$ & $6.97 \pm 0.93^{\mathrm{f}}$ & $6.47 \pm 1.28^{\mathrm{f}}$ & $6.37 \pm 1.71^{\mathrm{f}}$ & $6.87 \pm 1.28^{\mathrm{f}}$ \\
MFY & $7.00 \pm 1.20^{\mathrm{e}}$ & $6.57 \pm 2.05^{\mathrm{f}}$ & $6.80 \pm 1.71^{\mathrm{f}}$ & $6.93 \pm 1.51^{\mathrm{f}}$ & $7.10 \pm 1.73^{\mathrm{f}}$ \\
MED & $6.20 \pm 1.90^{\mathrm{f}}$ & $6.27 \pm 1.64^{\mathrm{f}}$ & $6.67 \pm 1.18^{\mathrm{f}}$ & $6.63 \pm 1.27^{\mathrm{f}}$ & $6.53 \pm 1.72^{\mathrm{f}}$ \\
KSK & $7.00 \pm 0.79^{\mathrm{e}}$ & $6.33 \pm 1.58^{\mathrm{f}}$ & $6.83 \pm 1.59^{\mathrm{f}}$ & $6.53 \pm 1.38^{\mathrm{f}}$ & $6.90 \pm 1.60^{\mathrm{f}}$ \\
\hline \multicolumn{4}{c}{ Values within a column with different superscripts are significantly different $(\mathrm{p}<0.05)$}
\end{tabular}

KEY: GAB - 100\% plantain flour; ORE - 90\% plantain flour blended with 10\% African Yam Bean flour; TAM - 80\% plantain flour blended with 20\% African Yam Bean flour; MFY - 70\% plantain flour blended with 30\% African Yam Bean flour; MED - 60\% plantain flour blended with 40\% African Yam Bean flour; KSK - 50\% plantain flour blended with 50\% African Yam Bean flour

Conclusion: It can be inferred from this study that substitution of African yam bean in the blends increased the chemical composition better than unripe plantain flour. The consumption of enriched blends should be encouraged due to its high protein content and acceptable functional properties. In vitro digestibility may be a subject of further research as well as shelf stability of the flours. Glycemic response of consumer, economics of large scale production and marketing strategies are recommended. Acknowledgement: The author wish to acknowledge the kind support of Prof. Olapade A. A. for his friendly supervision of this work. Also, interpretation of data 
was done by Miss Salome K. K and reviewed by Mrs. Awofadeju

\section{REFERENCES}

Abiodun, O; Akinoso, R (2014). Textural and sensory properties of trifoliate yam (Dioscorea dumetorum) flour and stiff dough 'amala'. $J$. of Food Sci. Technol. 52 (5): 2894-2901

Abioye, V; Olanipekun, B; Omotosho, O (2015). Effect of varieties on the proximate, nutritional and anti-nutritional composition of nine variants of African yam bean seeds (Sphenostylis stenocarpa). Donnish J. Food Sci. Technol. 1, 1721

Abulude, FO; Ojediran, VA (2006). Development and quality evaluation of fortified 'amala'. Acta Sci. Pol. Technol. Aliment, 5(2), 127- 134

Adebowale, KO; Olu-Owolabi, BI; Olawumi, EK; Lawal, OS (2005). Functional properties of native, physically and chemically modified breadfruit (Artocarpus artillis) starch. Industr. Crops Prod. 21: 343-351

Adebowale, ARA; Sanni, SA; Oladapo, FO (2008). Chemical, functional and sensory properties of instant yam bread fruit flour. Nig. J. Food 26:212

Adeniyi, TA; Sanni, LO; Barimalaa, LS; Hart, AD (2006). Determination of micronutrients and colour variability among new plantain and banana hybrid flour W. J. Chem. 1(1): 23-27

Ade-Omowaye, BIO; Tucker, GA; Smetanska, I (2015). Nutritional potential of nine underexploited legumes in Southwest Nigeria. Int. J. Food Res 22, 798-806

Adeyeye, EI; Oshodi, AA; Ipinmoroti, KO (1994). Functional properties of some varieties of African yam bean (Sphenostylis stenocarpa) flour II. Int. J. Food Sci. Nutr 45, 115-126

Ajibola, GO; Olapade, AA (2016). Physical, proximate and anti-nutritional composition of African yam bean (Sphenostylis stenocarpa) seeds varieties. J. Food Res. 5, 67

Akinsanmi, A (2015). Assessment of the nutritional, anti nutritional and antioxidant capacity of unripe, ripe and over ripe plantain (Musa paradisiacal) peels. Int. J. Adv. Res. 3(2): $63-72$
Akinsola, AO; Segilola, VO; Ayoola, RB; Gbadegesin, IO (2021). Nutritional Quality And Sensory Properties Of Instant Plantain Flake Enriched With Egg Parts. Multidisc. Acad. J. Pub. 13(1): 41-50

Akinsola, A; Segilola, V; Oloso, S; Durojaiye, O (2018). Quality evaluation of plantain-African yam bean flour blends and sensory properties of its cooked (amala) paste. Res. J. Food Sci. Nutr. $3,31-40$

Amakoromo, E; Innocent-Adiele, H; Njoku, H (2012). Microbiological quality of a yoghurt-like product from African yam bean. Nat. Sci. 10, 6-9

Aniedu, C; Aniedu, OC (2014). Fortification of Cassava fufu flour with African yam bean flour: implications for improved nutrition in Nigeria. Pelagia Res. Libr. Asian J. Plant Sci. Res. 4, 6366

Anya, MI; Ozung, PO (2019). Proximate, mineral and anti-nutritional compositions of raw and processed African Yam bean (Sphenostylis stenocarpa) seeds in Cross River State, Nigeria. Global J. Agric Sci. 18, 19

AOAC (2000). Official Methods of Analysis, 18th Ed. Association of Official Analytical Chemists, Washington D.C, USA

Awoyale, W; Maziya-Dixon, B; Sanni, L; Shittu, TA (2010). Nutritional and sensory properties of amala supplemented with distiller's spent grain (DSG). J. Food, Agric. Environ. 8(3\&4), 66-70

Ayo-Omogie, H; Ogunsakin, R; (2013). Assessment of chemical, rheological and sensory properties of fermented maize-cardaba banana complementary food. Food Nutr. Sci. 4, 844-850

Babarinde, G; Adeyanju, J; Omogunsoye, A (2019). Protein enriched breakfast meal from sweet potato and African yam bean mixes. Bang. J. Sci. Ind. Res. 54, 125-130

Bhat, R; Karim, AA (2009). Exploring the nutritional potential of wild and underutilized legumes. Compr. Rev. Food Sci. Food saf. 8(4), 305-331

Daramola, B; Osanyinlusi, S (2006). Investigation on modification of cassava starch using active components of ginger roots (Zingiber officinale Roscoe). Afri. J. Biotech. 5(10), 917-920 
Duodu, KG; Apea-Bah, FB (2017). African Legumes: Nutritional and Health-Promoting Attributes. Gluten-free Ancient Grains: Cereals, Pseudocereals, and Legumes: Sustainable, Nutritious, and Health-Promoting Foods for the 21st Century. Elsevier Ltd

Edem, DO; Amugo, CI; Eka, OU (1990). Chemical composition of yam beans (Sphenostylis stenocarpa). Trop. Sci. 30, 59-63

Eleazu, CO; Okafor, PN; Amajor, J; Awa, E; Ikpeama, AI; and Eleazu, KC (2013). Chemical composition, antioxidant activity, functional properties and inhibitory action of unripe plantain (M. Paradisiacae) flour. Afr. J. Biotechnol., 10(74): 16937-16947

Eleazu, C; Okafor, P; Ahamefuna, I (2010). Total antioxidant capacity, nutritional composition and inhibitory activity of unripe plantain (Musa paradisiacae) on oxidative stress in alloxan induced diabetic rabbits. Pak. J. Nutr., 9, 10521057

Enujiugha, VN; Talabi, JY; Malomo, SA; Olagunju, AI (2012). DPPH radical scavenging capacity of phenolic extracts from African yam bean (Sphenostylis stenocarpa). Food Nutr. Sci. 3, 713

Eromosele, CO; Arogundadade, LA; Eromosele, IC; Ademuyiwa O (2008). Extractability of African yam bean (Stenophylis stenocarpa) protein acid, salt and alkaline aqeous media. Food Hydrocolloids, 22: 1622-1628

Falade, KO; Olugbuyi, AO (2010). Effects of maturity and drying method on the physic-chemical and reconstitution properties of plantain flour. Int. J. Food Sci. Technol. 45(1), 170-178

Falade, KO; Oyeyinka, SA (2014). Color, Chemical and Functional Properties of Plantain Cultivars and Cooking Banana Flour as Affected by Drying Method and Maturity. J. Food Process. Preserv. doi:10.1111/jfpp.12292

Foster, GD; Wyatt, HR; Hill, JO; (2003). A randomized trial of a low carbohydrate diet for obesity. New Eng. J. Med. 348: 2082-2090

Idowu, AO (2014). Development, nutrient composition and sensory properties of biscuits produced from composite flour of wheat and
African yam bean. Br. J. Appl. Sci. Technol. 4, 1925-1933

Idowu, AO (2015a). Chemical composition and sensory and pasting properties of blends of maizeAfrican yam bean seed. J. Nutr. Health Food Sci. $3,1-6$

Idowu, AO (2015b). Nutrient composition and sensory properties of kokoro (a Nigerian snack) made from maize and African yam bean flour blends. Int. Food Res. J. 22, 739-744

Igbabul, B; Num, G; Amove, J (2014). Quality Evaluation of Composite Bread Produced from Wheat, Maize and Orange Fleshed Sweet Potato Flours. Amer. J. Food Sci. Technol. Vol. 2(4): 109-115

Iwe, MO; Onyeukwu, U; Agiriga, AN (2016). Proximate, functional and pasting properties of FARO 44 rice, African yam bean and brown cowpea seeds composite flour. Cog. Food Agric. Doi.org/10.1080/23311932.2016.1142409

Jimoh, K; Olatidoye, O (2009). Evaluation of physicochemical and rheological characteristics of soybean fortified yam flour. J. App. Biosci. 13 703-706

Karim, O; Kayode, R; Oyeyinka S; Oyeyinka A (2015). Physicochemical properties of stiff dough "amala" prepared from Plantain (Musa paradisca) flour and moringa (Moringa oleifera) leaf Powder. Hrana u zdravlju $i$ bolesti, znanstveno-stručni časopis za nutricionizam $i$ dijetetiku 4 (1) 48-58

Klu, GYP; Amoatey, D; Bansa and Kumaga FK. (2001).Cultivation and use of African yam bean (Stenophylis stenocarpa) in volta region of Ghana. J. Food Technol. Afr. 6(3): 74-77

Ndidi, US; Ndidi, CU; Olagunju, A; Muhammad, A; Billy, FG; Okpe, O (2014). Proximate, antinutrients and mineral composition of raw and processed (boiled and roasted) Sphenostylis stenocarpa seeds from Southern Kaduna, Northwest Nigeria. ISRN Nutr. 1-9

Nwokolo, E (1987a). A nutritional assessment of African yam bean Sphenostylis stenocarpa (Hochst ex A. Rich) Harms, and Bambara groundnut Vigna subterranea L. J. Sci. Food Agric. 41, 123-129 
Nwosu, JN (2013). Evaluation of the proximate composition and antinutritional properties of African yam bean (Sphenostylis sternocarpa) using malting treatment. Int. J. Basic Appl. Sci. 2, 157-169

Oyeyinka, S; Oyeyinka, A; Karim, O; Kayode, R; Balogun, M; Balogun, O (2013). Quality attributes of weevils (Callosobruchus maculatus) infested cowpea (Vigna unguiculata) products. Nig. J. Agri. Food Environ. 9: 16-22

Riaz-Mian, N; Swanmylingappa, B (2006). Chemical, functional, and nutritional characteristics of weaning food formulation. In Souvenir, 41st National Conference of Nutrition Society of India on chronic diseases. The new pre-endemic, National Institute of Nutrition Hyderedal, pp. 96
Singh, U (2001). Functional properties of grain legumes flours. J. Food Sci. 38:191-199

Uchegbu, NN (2015). Antioxidant activity of germinated African yam bean (Sphenostylis stenocarpa) in Alloxan diabetic rats. Int. J. Nutr. Food Eng. 9, 206-210

Ukegbu, P; Uwaegbute, A (2014). Vitamin, Mineral and Anti Nutrient Content of Bambara Groundnut Pudding (okpa) (Voandzeia Subterranean L. Thouars) Produced by Different Methods. J. Nutri. Eco. Food Res. 2: 69-72.

Willett, W; Manson, J; Liu, S (2002). Glycemic index, glycemic load, and risk of type 2 diabetes. Amer. J. Clinical Nutr. 76 (2): 74-80 